ISBN 978-93-5137-179-3

ISSN

$2320-7329$

Ayurlog: National Journal of Research in Ayurved Science

\title{
Dialogue and debate as represented in Charaka samhita A major treatise of Ayurveda
}

\section{Khati G.Y. 1 , Vinay Ankush Pawar*², Sumant Avinash Khardenavis ${ }^{2}$,}

1. Dean, R. A. Podar Medical College (Ayu), Worli, Mumbai-18.

2. Associate Professor, Dept of Sanskrit Samhita Siddhant, D. Y. Patil University, School of Ayurveda, Nerul, Navi Mumbai.

3. Assistant Professor, Dept. of Sanskrit Samhita Siddhant, R.A.Podar Medical College (Ayu), Worli, Mumbai. Email - sumantkhardenavis@gmail.com, Mobile No. 9819852651

*Corresponding Author: vinay10882@yahoo.com; Mobile No. 7506631982

\section{Abstract:}

Ayurveda, the traditional Indian medicinal system remains the most ancient yet living traditions with sound philosophical and experimental basis. Charaka Samhita, one of the major treatises of Ayurveda, talks about the various aspects of ayurvedic contexts in treating diseases and in preventing them. In Vimanasthana, Charakacharya has mentioned three different means of gaining knowledge (Trividha gyanopaya) of science as - Adhyayana (learning), Adhyapana (teaching) and Tadvidya-Sambhasha (discussions and debates). This third means of gaining knowledge, TadvidyaSambhasha, is a method of discussion and debate between two knowledgeable physicians in the presence of viewers. Tadvidya-Sambhasha, i. e. assembly of physicians is important for eradicating doubts with regard to the line of treatment. Tadvidya-Sambhasha is of two types, viz. SandhayaSambhasha (friendly discussions) and Sandhaya-Sambhasha (hostile discussions). This paper tries to study dialogue and debate as represented in one of the major treatises of Ayurveda i. e., Charaka Samhita. It's an attempt to show scientific nature of those dialogues and debates and their applications in the field of medical science for advancement of knowledge.

KEYWORD: Tadvidya-Sambhasha, Sandhaya-Sambhasha, Sandhaya-Sambhasha, Vada 


\section{INTRODUTION:}

History of medicine is a fascinating subject as it is a saga of man's struggle against disease. As the civilisation advances and as the disease pattern changes, the medical science also changes. Ayurveda is the system of medicine evolved in India and survived as a distinct entity from remote antiquity to present day.

Ayurveda, the traditional Indian medicinal system remains the most ancient yet living traditions with sound philosophical and experimental basis. Ayurveda shows resemblance with Darshanas, which teach relentless and objective search for truth. Brihattrayi, i. e. three major treatises of Ayurveda namely - Charaka Samhita, Sushruta Samhita and Vagbhata Samhita (Ashtanga Samgraha and Ashtanga Hridaya) emphasize mainly on Tri-sutras Hetu (etiological factors), Linga (symptoms and signs) and Aushadha (treatment). To achieve four goals of life (Dharma, Artha, Kama and Moksha), health is given the prime importance. ${ }^{[1]}$ Charaka Samhita, one of the major treatises of Ayurveda, talks about the various aspects of ayurvedic contexts in treating diseases and in preventing them. The presently available Charaka Samhita mentions Punarvasu Atreya, Charaka, and Drudhabala. Punarvasu Atreya is believed to have preached Ayurveda to his student Agnivesha, who composed the text which Charaka redacted and Drudhabala completed.

The period of Punarvasu Atreya is considered to be $1000 \mathrm{BC}^{[2]}$ The royal physician of king Kanishka was Charaka. Hence, the period of Charaka may be taken as second century BC. ${ }^{[3]}$ The period of Drudhabala is taken as $400 \mathrm{AD}^{[4]}$

Charaka Samhita constitutes of 8 sthanas (parts) with a total number of 120 chapters mainly focusing onKayachikitsa - the diagnosis and healing of illnesses through internal and external use of medicine. This branch of Ayurveda aims at healing the mind \& the body, thus striking a balance between the two great pillars of the human soul. Charaka Samhita, laid foundation for logical analysis of the subject matter. As stated in Charaka Samhita, 'It is not easy to acquire comprehensive knowledge of the 'Science of life'. Therefore one should make honest efforts to be in constant touch with this science. The wise consider the entire universe as their preceptor; it is only the unwise who consider it to be their enemy. ${ }^{[5]}$

In Vimanasthana, Charakacharya has mentioned three different means of gaining knowledge (Trividha gyanopaya) of science as - Adhyayana (learning), Adhyapana (teaching) and TadvidyaSambhasha (discussions and debates). ${ }^{[6]}$

The initial part of the chapter deals with the preliminaries of choosing the medical career and with the choice of a teacher in this field, and then general requirements and rules for Adhyayana (studying) and Adhyapana (teaching), including the selection of a student by a teacher and the former's ritual initiation into student hood [7-9] This third means of gaining knowledge is known as Tadvidya-Sambhasha. ${ }^{[10]}$ It is a method of debate between two knowledgeable physicians in the presence of viewers.

\section{Conceptual study:}

The literary meaning of the word 'Tadvidya-Sambhasha' is scholarly discussion between two or more subject experts which is correlated with modern seminars and symposia. Conference is a formal meeting of people with a shared interest, typically taken place over several days. ${ }^{[11]}$ Seminar is a conference or other meeting for discussion or training of a small group of students at university, meeting to discuss topics with a teacher. ${ }^{[12]}$ Symposium is a conference to discuss a particular academic or specialist subject. $^{[13]}$ All these three share similar concern, i. e. analysis of a new or 
established concept through a series of scientific discussions.

Sambhasha - Vidhi: A physician should participate in a discussion with another physician. Professional discussion indeed promotes the power of application of knowledge and competition leading to enlightenment. It manifests the clarity of knowledge, promotes the power of speech, spreads fame, eliminates doubts reminiscent of the previous study by repeated hearing and brings about confirmation of what is undoubtedly understood before.

During the course of discussions, one comes to know of many new things which were not heard by one previously. Being pleased over the devoted disciple, the preceptor during the course of teaching elaborates some secret meanings. The participants during the course of mutual discussion enthusiastically disclose these secret meanings in brief with a view to achieving a victory over the competitor. Therefore, participation in professional debates is always appreciated by the wise. $^{[14]}$

Tadvidya-Sambhasha, i. e. assembly of physicians is important for eradicating doubts with regard to the line of treatment. [15]

Tadvidya-Sambhasha (Professional discussions) are of two types, viz.

i. Sandhaya-Sambhasha(friendly discussions)

ii. Vigruhya-Sambhasha (hostile discussions) ${ }^{[16]}$

\section{Procedure for Sandhaya- Sambhasha (friendly discussions) $^{[17]}$}

One should have friendly discussions with persons of learning possessed of scientific knowledge, power of argument and counter argument, who do not get irritated, who are endowed with correct knowledge, who are not jealous, who can be made to understand, who are competent in convincing others, who are capable of facing difficult situations and who can address in a sweet tone.

One should confidently discuss with such persons and put questions to them. When he asks anything, it should be elaborately described with confidence. One should not get worried under the apprehension of getting defeated, one should not rejoice by defeating his opponents. One should not show off of having defeated such opponents. One should not hold extreme views under delusion. One should not try to describe thing which the other party does not know. One should try to bring round the other party with politeness and not by deception. One should be very careful to behave politely with his opponents.

\section{Vigruhya- Sambhasha (hostile discussions) ${ }^{[18]}$}

With persons other than preceptor and class-mates, one should go in for hostile discussions provided he is confident of his superiority. Before entering into discussion, the procedure proposed to be adopted by the opponent, difference between the abilities of himself and the opponent and the disposition of the members of the assembly should be carefully examined.

'A wise person determines the time of entering or giving up the discussion only by proper examination. Hence proper examination is always advisable.'

There are some good and bad qualities of the participants in a discussion. With a view to determining the superiority or inferiority of himself with respect to his opponent, one should carefully examine these good and bad qualities.

Good qualities of participants are: Shrutam (the knowledge of the text), vigyanam (practical experience), dharanam (power of retention), pratibhanam (presence of mind) and vachanashakti (power of expression). 
Bad qualities of participants are: kopanatvam (irritation), avaishradyam (lack of skills), bheerutvam (cowardice), adharanatvam (lack ofpower of retention) and anavahitatvam (carelessness).

\section{Three types of opponent:}

Depending upon the presence of the above mentioned qualities, the opponent may belong to either of the three categories, viz. i) Pravara (superior), ii) Pratyavara (inferior) or iii) Sama(equal). However, other factors like the family status, conduct, religions etc., should not be taken into account in this connection. ${ }^{[19]}$

\section{Two types of assembly:}

An assembly is of two types, viz. i) Gyanavati (intelligent) and ii) Mooḍa (dull). On the basis of different criteria, both these types of an assembly may be classified into three types, viz. i) Suhrutparishat (friendly), ii) Udasinaparishat (neutral) and iii) Pratinivishthaparishat (prejudicial). ${ }^{[20]}$

\section{Procedure for debate:}

i. Members of the assembly may be enlightened or dull but if they are prejudicial, and then one should never enter into discussion with anybody, not even with the most wretched one in such an assembly.

ii. If the members of the assembly are dull but friendly or neutral, then the individual should enter into discussion with an opponent who is not very famous and who is even despicable by great people even without theoretical and practical knowledge or power. While discussing with such an opponent, one should use long sentences as are difficult to understand or are composed of long and complicated aphorisms. An overexcited opponent should be ridiculed and the individual should continue his speech acting as if addressing the assembly, without giving an opportunity for the opponent to speak.
One should speak using such terms as are difficult to understand and the opponent should be told that he was incapable of advancing any argument in the matter and his proposition has failed. Once the opponent is defeated he remains defeated forever; hence his further challenge for discussion should not be accepted.

iii. Some people advise the same procedure should be followed while discussing with a superior opponent. But the wise do not approve of such a proposition to enter into hostile discussion with a superior opponent. While discussing with the opponent in a debate, members of which are not enlightened, one should use complicated sentences so that members of the assembly will find it very difficult to understand. By implication, the user of such words and sentences will be credited with success. ${ }^{\text {[21] }}$

iv. With an opponent of inferior or equal type, one should enter into hostile discussion if the members of the assembly are favourably inclined towards him. In an assembly where members are neutral and are attentive, inclined to hear, learned, experienced, having the power of retention, speech and contradiction; one should carefully observe the good and bad qualities of the opponent as a participant in the discussion.

v. On the basis of observation, if the opponent is found to belong to superior category, then one should not enter into discussion on the same topic. Without letting the assembly know, he should change the topic of discussion to a favourable one. If the opponent is found to be of inferior category then the efforts should be made to defeat him immediately in a hostile discussion.

vi. The following procedure should be adopted for immediately defeating an opponent of inferior category. If opponent is not a learned person, then 
he should be defeated by citing long aphorisms; if he is not experienced then by such words and sentences as are difficult to understand; if he is unable to retain sentences by memory then by sentences composed of complicated and long aphorisms; if he is dull then by statements of the same type but carrying different meanings; if he is devoid of the power of oration then by challenging with half of a sentence; if he has no experience of participating in seminars then by putting him to a disgraceful situation; if he is irritable, then by creating difficult situations for him; if he is a cowardice then by creating fearful situations and if he is not careful then by adhering to discipline of discussion. ${ }^{[22]}$

Thus it is said:

"In fighting discussions one should make careful statements and should not overrule the statements of opponents which are well authenticated. Some people get excessively irritated during hostile discussions and there is nothing which cannot be done or said by the enraged one. Therefore, in an assembly of learned people, the wise never appreciate a quarrel."[23]

For discussions in a debate, one should prevail upon the assembly to select such a topic in which the individual is already well versed with and which might be too difficult for the opponent. The opponent should be led to state such an aspect of the argument which will generally find disfavour with the members of the assembly e. g. nobody would like argument against the established theories like the existence of Paraloka and Karmaphala and if the opponent is led to state, this view in a debate, he can be easily defeated. ${ }^{[24]}$

The following factors bear importance in determining the limits of a fighting debate:

1. Things should be said;

2. Things which should not be said; and

3. The point of defeat. ${ }^{[25]}$
These three factors are to be kept in view only in the case of hostile discussion or debate. The friendly discussion is always associated with a desire to determine the truth.

- Vadamargapadani (Logical terms to be acquainted with the debaters ${ }^{[26]}$ :

1. Vada (debate)

2. Dravya (substance)

3. Guna (attributes)

4. Karma (action)

5. Samanya (generic concomitance)

6. Vishesha (variant factor)

7. Samavaya (inseparable concomitance)

8. Pratijna (proposition)

9. Sthapana (justification)

10. Pratishthapana (counter argument)

11. Hetu (cause)

12. Drishtanta (example)

13. Upanaya (subsumptive correlation)

14. Nigamana (final conclusion)

15. Uttara (rejoinder)

16. Siddhanta (concluded truth)

17. Shabda (words)

18. Pratyaksha (direct observation)

19. Anumana (inference)

20. Aitihya (words of divine origin)

21. Aupamya (analogy)

22. Samshaya (doubt)

23. Prayojana (object)

24. Savyabhichara (statements with exceptions)

25. Jijnasa (enquiry)

26. Vyavasaya (determination)

27. Arthapatti (implied meaning)

28. Sambhava (source)

29. Ananuyojya (defective statement)

30. Anuyojya (infallible statement)

31. Anuyoga (scriptural enquiry)

32. Pratyanuyoga (scriptural counter enquiry)

33. Vakyadosha (syntactical defects)

34. Vakyaprasamsa (syntactical excellence)

35. Chhala (justification)

36. Ahetu (casual fallacy) 
37. Atitakala (defiance of temporal order)

38. Upalambha (pointing out defects in justification0

39. Parihara (correction)

40. Pratijnahani (shift from the original proposition)

41. Abhyanujna (confessional retort)

42. Hetvantara (fallacy of reason)

43. Arthantara (irrelevant statement)

44. Nigrahasthana (clinchers)

\section{Vada (debate):}

A debate may be defined as a hostile discussion with an opponent based on scriptures. This is of two types, viz. i) jalpa (disputation) ii) vitanda (wrangling). Advancement of one's own view while contradicting the opponent is jalpa (disputation); otherwise the discussion is vitanda (wrangling). For example, if one of the participants debates in favour of the existence of Punarjanma (rebirth) and the other against it, and both of them advance arguments in support of their own views contradicting the other's view point; this is known as jalpa (disputation). In vitanda (wrangling) type of debate, only the opponents' views are contradicted without advancing arguments in support of the individuals own views. ${ }^{[27]}$

A critical scientific approach of science of Ayurveda is evident from the concept of Siddhanta, which Charakacharya has mentioned as one of the 44 methods of debate.

A demonstrated truth, established after several examinations \& reasoning is known as Siddhanta. ${ }^{[28]}$

Siddhānta is of four types:

1. Sarvatantra Siddhanta (common to all branches of knowledge)

2. Pratitantra Siddhanta (specific to a given branch of knowledge)

3. Adhikarana Siddhanta (truth implied in given context)

4. Abhyupagama Siddhanta (hypothesis or postulate)
Applications of other Vadamargapadani have also been indicated as per the condition during debate.

\section{Seminars and symposia in Charaka- Samhita:}

All the streams of science have been evolved as a process of continuous development. This includes teaching, research as well as sharing of thoughts through various conferences, seminars and symposia.

Following Parishads have been mentioned in Charaka Samhita.

\section{Ayurvedavatarana Parishad:}

The main aim of this conference was to find out a solution for the diseases that originated in all the living beings after end of Satyuga. Diseases are destroyers of health, well-being and life. This has manifested itself as a great obstacle in the way of human life. It was a formal meeting of the sages to find out solution for common problem. ${ }^{[29]}$

\section{Vatakalakaliya Parishad:}

The main aim of this symposium was to know about the good and bad qualities of Vata mainly. But the later discussion also throws light on the properties and actions of Pitta and Kapha also. Initially the sages started to express their views and opinions followed by presidential remark by Acharya Punarvasu Atreya which was welcomed by all the sages. ${ }^{[30]}$

\section{Rashipurusha}

evam rogotpattivishayaka Parishad:

The aim of this symposium was to determine the origin of man - an aggregate of soul, senses and mind and his diseases. The sages started expressing their own views and refuting the views of other sages. During the course of this controversial discussion of the sages, Acharya Punarvasu Atreya concluded that one should not enter into such a controversy, as it is very difficult to arrive at truth by taking sides with its partial aspects. Those who consider the varying 
controversial aspects of the truth as established facts, go on moving around without reaching goal like a person sitting on the oil press. ${ }^{[31]}$

\section{Rasa-ahara \\ Parishad:}

The main aim of this symposium appears to be to decide the number of Rasas. All the participants except Acharya Punarvasu Atreya proposed their theories for the number of rasas. Acharya Punarvasu Atreya concluded that there are only six rasas and he countered the opinions of the participants with solid logics. ${ }^{[32]}$

\section{Garbhavakrantivishayaka Parishad:}

In the beginning, Acharya Punarvasu Atreya explains the process of formation of foetus and mentioned six factors responsible for foetus formation viz. mother, father, satmya, atma, rasa and satva. Another sage Bharadvaja refuted this theory and counted causality of all the factors one by one. Acharya Punarvasu Atreya with utter confidence restated the causality of all the factors and established the same with logical explanation. The debate between Acharya Punarvasu Atreya and sage Bharadvaja went on. Acharya Punarvasu Atreya advised sage Bhāradvaja that he should accept the conclusion and abandon all the doubts. ${ }^{[33]}$

\section{Garbha \\ anga-pratyanga- nivrittivishayaka Parishad:}

In this context, Atreya Punarvasu was asked by his disciple Agnivesha if which organ of the foetus is manifested first in the womb of the mother. Lord Punarvasu Atreya replied to Agnivesha that the manner in which the foetus is formed in the uterus of the mother and the mode of manifestation of its various organs is describes already but there are various queries. $^{[34]}$

\section{Madanaphalavishayaka Parishad:}

This symposium is mentioned in Siddhisthana of Charaka Samhita by Acharya Drudhabala. The main aim of the symposium was to resolve dispute over the most useful ingredients from amongst Madana-phala, etc. for asthapana-basti and to determine the excellence of asthapana-basti with Madana-phala, etc. in specific ailments. Having heard all the interesting statements of the sages, Punarvasu Atreya admired the efforts of the speakers and delivered the final judgement. He supported his judgement with logical explanation which was honoured by the assembly of sages. ${ }^{[35]}$

\section{Discussion:}

1. Enquiry and investigation have remained the major strengths of the Indian system since ancient times. The traditional Gurukula system involved close and significant interactions between a teacher and his disciples, providing the latter with unique opportunities for imbibing the teacher's virtues, learning style and clinical experiencing of Ayurveda entities.

2. Ayurveda pedagogy has a complex challenge for inculcating a deeper understanding of the shastras as well as to transmit the concepts of scientific basis of decisions for the treatment of patients.

3. Tadvidya-Sambhasha, i. e. assembly of physicians is important for eradicating doubts with regard to the line of treatment.Tadvidya-Sambhasha is considered a didactic means to be employed beneficially in medical training and a useful tool in the continuing and improvement of medical knowledge.

4. Sandhaya-Sambhashais distinguished from Vigruhya-Sambhasha, terms and notions clearly related to the concepts of Sandhi (alliance) and Vigraha (conflict).

5. Dialogue assumes that many people have pieces of the answer and that together, they can craft a solution. It is collaborative in nature - participants work together toward a common 
understanding. It is about exploring common good. This can be clearly correlated with Sandhaya-Sambhasha as explained in Caraka Samhita.Ayurvedavatarana Parishad, Vatakalakaliya Parishad, Rasa-ahara - vinishcayartha Parishad, Garbha anga-pratyanga-niv!ttivishayaka

Parishadand Madanaphalavishayaka Parishadare the examples of Sandhaya-Sambhasha or friendly discussions.

6. Debate is combative in nature participants attempt to prove the other side wrong. It is about winning and entails listening to find flaws and make counter arguments. This can be clearly correlated with Vigruhya-Sambhasha as explained inCharaka Samhita. Charakacharyagives various practical advices to the disputants, inclusive of advance manipulation of the assembly.Rashipurusha evam rogotpattivishayaka Parishad and Garbhavakrantivishayaka Parishad are the examples of VigruhyaSambhasha or hostile discussions.

7. Charaka Samhita clearly directs that one should not enter into a controversy, as it is very difficult to arrive at truth by taking sides with its partial aspects. Those who consider the varying controversial aspects of the truth as established facts, go on moving around without reaching goal like a person sitting on the oil press. All the symposia that are described in Charaka Samhita have one thing in common i. e. the chief speaker or presidential speaker in all the symposia are the ones that are considered as the teacher of the Tantrakarta. Thus, in all the seminars, the final concluding remark is given by Punarvasu Atreya.

\section{Conclusion:}

Charaka Samhita throws light on the dialogues and debates in ancient India necessaryfor inculcating a deeper understanding of the shastras as well as to transmit the concepts of scientific basis of decisions for the treatment of patients.

\section{References:}

1. Agnivesha, Charaka Samhita elaborated by Charaka \& Drudhabala with Ayurveda-Dipika Commentary by Chakrapanidatta, edited by Vaidya Jadavaji Trikamji Acharya, Varanasi, Choukhambha Surbharati Prakashan, Reprinted 2005, Sutrasthana chapter 1, verse no.15, p. 6.

2. Sharma PV, Ayurveda Ka Vaignanik Itihas, Varanasi: Chaukhambha Orientalia; 1975, p.88.

3. Ibid, p.105

4. Ibid, p.108

5. Agnivesha, Charaka Samhita elaborated by Charaka \& Drudhabala with Ayurveda-Dipika Commentary by Chakrapanidatta, edited by Vaidya Jadavaji Trikamji Acharya, Varanasi, Choukhambha Surbharati Prakashan, Reprinted 2005, p. 264.

6. Ibid, verse no. 15 , p. 264

7. Ibid, verse no. 3 , p. 261

8. Ibid, verse no.7, p. 262

9. Ibid, verse no.8, p. 262

10. Ibid, verse no.6, p. 262

11. Angus Stevenson et al., editors. Oxford dictionary of English, $3^{\text {rd }}$ ed. Oxford Uni. Press. 2010,p.365

12. Ibid, p.1619

13. Ibid, P.1803

14. Ibid, Vimanasthana chapter 8 , verse no.15, page no. 264.

15. Agnivesha, Charaka Samhita elaborated by Charaka \& Drudhabala with Ayurveda-Dipika Commentary by Chakrapanidatta, edited by Vaidya Jadavaji Trikamji Acharya, Varanasi, Choukhambha Surbharati Prakashan, Reprinted 2005, Sutrasthana chapter 25, verse no.40, p. 132.

16. Ibid, Vimanasthana chapter 8 , verse no.16, page no. 264.

17. Ibid, verse no. 17 , p. 264

18. Ibid, verse no. 18 , p. 265

19. Ibid, verse no. 19 , p. 265

20. Ibid, verse no. 20 , p. 265 
21. Ibid, verse no. 20 , p. 265

22. Ibid, verse no. 21, p. 266

23. Ibid, verse no.22-24, p. 266

24. Ibid, verse no. 25 , p. 266

25. Ibid, verse no.26, p. 266

26. Ibid, verse no. 27 , p. 266

27. Ibid, verse no.28, p. 266

28. Ibid, verse no.37, p. 268

29. Agnivesha, Charaka Samhita elaborated by Charaka \& Drudhabala with Ayurveda-Dipika Commentary by Chakrapanidatta, edited by Vaidya Jadavaji Trikamji Acharya, Varanasi, Choukhambha Surbharati Prakashan,
Reprinted 2005, Sutrasthana chapter 1, verse no.8-23, p. 6.

30. Ibid, Sutrasthana chapter 12, verse no.3-14, p. 78.

31. Ibid, Sutrasthana chapter 25, verse no.3-28, p. 127.

32. Ibid, Sutrasthana chapter 26, verse no.3-9, p. 135.

33. Ibid, p. 268

34. Ibid, Sharirasthana chapter 3, verse no.3-14, p. 334.

35. Ibid, Siddhisthana chapter 11, verse no. $3-14$, p. 727.

\section{Cite this article:}

Dialogue and debate as represented in Charaka samhita -A major treatise of Ayurveda Khati G.Y., Vinay Ankush Pawar, Sumant Avinash Khardenavis

Ayurlog: National Journal of Research in Ayurved $S_{\text {cience-2017; 6(1): 1-9 }}$ 